\title{
DETECTION OF METHICILLIN RESISTANT AND SLIME FACTOR PRODUCTION OF COAGULASE NEGATIVE STAPHYLOCOCCUS SPP. IN BOVINE CLINICAL MASTITIS BY USING PCR
}

\author{
S.M. EL-BERBAWY*; S.M. SAYED*; E.I. EL-TOUKHY** and AMAL A. MEGAHED ${ }^{* * *}$ \\ * Animal Health Research Institute (AHRI), Bacteriology Dept., Assiut Lab. \\ ***Animal Health Research Institute (AHRI), Biotechnology Dept., Dokki. \\ *** Port Said Lab., Bacteriology Dept. \\ Email: saadelberbawy@yahoo.com
}

\section{ABSTRACT}

Received at: 24/12/2014

Accepted: 18/1/2015

\begin{abstract}
The aim of this study was to determine and investigate the slime production of Coagulase negative staphylococci (CoNS) isolates by phenotypic method on Congo Red Agar plates (CRA) and Genotypic detection of icaA, icaD and mecA genes by polymerase chain reaction (PCR). The study was done on 105 milk samples obtained from bovine clinical mastitis and found that 101samples $(96.2 \%)$ were positive for bacterial culture. CoNS species can be isolated from20 samples with a percentage $19.8 \%$. Their ability to form biofilm as one of the most important virulence factors using Congo Red Agar (CRA) method was investigated, in which 13 out of 17 CoNS isolates (76.47\%) were found to be slime producers. By PCR, mecA gene was found in threeout 6 CoNS isolates $(50 \%)$. Also, six $(100 \%)$ and three $(50 \%)$ isolates were positive for icaA gene and icaD gene, respectively, and 3 isolates $(50 \%)$ were positive for both icaA and icaD genes. In addition, one out of the six CoNS isolates (16.67\%) was positive for the presence of $i c a A$, icaD and mecA genes and also it has the ability to form biofilm. Conclusion, findings of the present study demonstrated the ability of CoNS isolated from bovine clinical mastitis to form biofilms. This must be considered as an alarming situation, and so attention must be paid toward implementation of new ways for effective prophylaxis, control, and treatment of such infections in the dairy farms. The prudent use of antibiotics and rapid and continuous screening for resistant microorganisms should be more focused to prevent the emergence and spread methicillin resistant coagulase negative staphylococci, because these strains can cause severe damage to infected sites and may be widespread in the environment.
\end{abstract}

Key words: Cows, clinical mastitis, coagulase-negative staphylococci, slime factor, mecA, icaA \& icaD genes.

\section{INTRODUCTION}

Mastitis in dairy cows is a serious problem as it an economically devasting disease causing immense economic losses in the dairy industry in Egypt (El-Damaty, 2013). During recent years, coagulase negative staphylococci (CoNS) have become the most common bovine mastitis isolates in many countries and are regarded as emerging mastitis pathogens (Pyörälä and Taponen, 2009). The impact of CoNS is increasing, probably because prevalence of major pathogens is decreasing. Otherwise, the high frequency of CoNS and E. coli occurrence indicated insufficient hygiene of housing and milking causing the risk of environmental mastitis (Idriss et al., 2013).

Coagulase negative staphylococci are always present on the udder skin and in teat canals; under favourable conditions they permeate the galactogenic pathway to the quarter. The pathogenic mechanisms of CoNS are expressed by two parameters: invasiveness (ability to permeate through protective barriers, to adhere to host cells and to form a biofilm) and toxicity [capacity to produce enzymes and toxins, including haemolysins and proteases], (Bochniarz and Wawron, 2012).

Biofilm is an exopolysaccharide, a slime matrix around multiple layers of cells. The ability of Staphylococci to form biofilms is one of the virulence factors that facilitate the adherence and colonization of Staphylococci on the mammary gland epithelium, also contributing to the evasion of the immunological defenses and to the difficulty of pathogen eradication, leading to recurrent or persistent infections (Oliveira et al., 2006). Likewise, biofilm-producing isolates have been reported for many CoNS species, especially in S. epidermidis (Tormo et al., 2005 and 
Oliveira et al., 2006). Biofilm prohibits host immune defense by impairing phagocytosis and production of antimicrobial peptides by epithelial cells and neutrophils, it also protect bacteria from antimicrobial therapy (Cucarella et al., 2004 and Melchior et al., 2006). Biofilm consists of polysaccharide intercellular adhesion (PIA) encoded by the intercellular adhesion icaADBC operon (Stevens et al., 2008).

CoNS strains have become a serious problem as they express methicillin resistance, which involves all $\beta$ lactam antibiotics and leads to a significant limitation in therapeutic options. Methicillin resistance is associated with the presence of the mecA gene which encodes a penicillin-binding protein (PBP2a) with altered properties responsible for the observed resistance(Chambers, 1997).Incidence of methicillin resistance in CoNS is high, as well as, the accompanying antimicrobial resistance (Bogado et al., 2001).

Resistance to $\beta$-lactamase-resistant penicillins, or methicillin resistance, depends on a complex expression mechanism of the mecA gene, which is often species-idiosyncratic among staphylococci (Chambers, 1997). Methicillin resistance may result from a series of factors including high degree of intrinsic resistance, hyperproduction of $\beta$-lactamase or mecA-associated resistance. These factors may operate and interact in the same strain (De Lencastre et al., 1991 and Unal et al., 1992). The mecA gene encoding methicillin resistance is widely disseminated among various Staphylococcus species. This widespread distribution of mecA might be due to the horizontal transmission between CoNS isolates and Staph. Aureus (Archer and Niemeyer, 1994).

In CoNS, which display a complex regulation of methicillin resistance, PCR amplification provides the most reliable test for identification of methicillin resistant coagulase negative staphylococci (MRCoNS). Although the use of PCR-based determinations represents a significant increase in reagent costs relative to phenotypic reagents, their reliability, as well as, considerations of the time and labour, make these molecular methods increasingly recommendable for early detection of methicillin (Bogado et al., 2001).

Keeping in view the economic loss caused by the bovine mastitis and emergence of drug resistant CoNS, the present investigation was undertaken with the following objectives (i) assessment of prevalence of CoNS in clinical bovine mastitis in dairy cows and the antibiogram of the CoNS isolates (ii) investigate the slime production of CoNS isolates by phenotypic method on Congo Red Agar plates (CRA) (iii) Genotypic detection of mecA, icaA and icaD genes by polymerase chain reaction (PCR).

\section{MATERIALS and METHODS}

\author{
A - Milk samples collection and laboratory \\ analysis:
}

This study was done on 105 dairy cows with clinical mastitis admitted to Veterinary Clinic, in Assiut, Egypt. After physical examination and conformation of clinical mastitis, $20 \mathrm{ml}$ milk samples was taken aseptically from all quarters of animals suffering from clinical mastitis and immediately transferred cool to the laboratory.

Amount of $0.01 \mathrm{~mL}$ of each milk samples was cultured on blood agar with 5\% sheep blood, Mannitol salt agar (BBL) and MacConkey agar (Biomark Lab. India) which incubated at $37^{\circ} \mathrm{C}$ for 48 h. The suspected colonies were identified: morphologically, by Gram's stain and biochemically confirmed by using catalase activity, coagulase test,as well as, Novobiocin $(5 \mu \mathrm{g})$ and polymixin- $\beta$ sulphate (300 U) sensitivity tests, according to Quinn et al. (2004).

\section{B -In vitro antimicrobial susceptibility test:}

It was evaluated by using the disc-diffusion method on the Mueller-Hinton agar according to the guidelines of the National Committee for Clinical Laboratory Standards (NCCLS, 2002). Kirby- Bauer's disc diffusion technique was adapted for antibiogram. The CoNS strains susceptibility to the following antimicrobial (Bioanalyse-Turkey) was tested: Oxacillin (OX) $1 \mu \mathrm{g}$, Ampicillin (AM) $10 \mu \mathrm{g}$, Cefotaxime (CTX) $30 \mu \mathrm{g}$, Cloxacillin (CX) $1 \mu \mathrm{g}$, Doxycycline (DO) $30 \mu \mathrm{g}$, Enrofloxacin (ENR) $5 \mu \mathrm{g}$, Gentamicin (CN) $10 \mu \mathrm{g}$, Lincomycin (L) $2 \mu \mathrm{g}$, Oxytetracycline (T) $30 \mu \mathrm{g}$, Penicillin (P) $10 \mu$ and Trimethoprim-Sulflamethaxzole (SXT) $25 \mu \mathrm{g}$. Plates with discs were left at room temperature for 30 minutes and incubated at $35^{\circ} \mathrm{C}$ for $24 \mathrm{~h}$. For Oxacillin susceptibility determinations, inhibition zones around the disc were measured after 24 and $48 \mathrm{~h}$ using the following breakpoints: susceptible $(\mathrm{S}) \geq 18 \mathrm{~mm}$; resistance $(\mathrm{R}) \leq 17 \mathrm{~mm}$ (Quinn et al., 2004).

\section{C - Detection of slime production on Congo Red Agar medium:}

The medium was composed of brain heart infusion broth (Oxoid Ltd, Basingstoke, England) 37 g/ L, sucrose $50 \mathrm{~g} / \mathrm{L}$, agar No 1 (Oxoid) $10 \mathrm{~g} / \mathrm{L}$ and Congo red $0.8 \mathrm{~g} / \mathrm{L}$. Congo red stain was prepared as a concentrated aqueous solution and autoclaved $\left(121^{\circ} \mathrm{C}\right.$ for 15 minutes) separately from the other medium constituents, and was then added when the agar had cooled to $55^{\circ} \mathrm{C}$. Plates of the medium were inoculated and incubated aerobically for 24 hours at $37^{\circ} \mathrm{C}$. A positive result was indicated by black colonies with a dry crystalline consistency. Non-slime producers usually remained pink (Freeman et al., 1989). 
D - PCR for detection of mecA, icaA and icaD genes:

\section{Materials used for PCR:}

1.1. Reagents used for agarose gel electrophoresis: 1.1.1. Agarose powder, Biotechnology grade (Bioshop $^{\mathrm{R}}$, Canda inc. lot No: OE16323). It prepared in concentration $2 \%$ in $1 \times$ TAE buffer.

1.1.2. Tris acetate EDTA (TAE) electrophoresis buffer (50xliquid concentration) (Bioshop R, Canda inc. lot No: 9E11854). The solution diluted to $1 \times$ by adding $1 \mathrm{ml}$ stock solution to $49 \mathrm{ml}$ double dist. water to be used in the preparation of the gel or as a running buffer.

1.1.3. Ethidium bromide solution (stock solution) biotechnology grade (Bioshop $®$ Canda Inc, Lot No: 0A14667): The stock solution was diluted by $25 \mu 1$ $1200 \mathrm{ml}$ double distilled water and stored covered at $4^{\circ} \mathrm{C}$. It was used for staining of PCR products that electrophoreses on agarose gel to be visualized by UV light.
1.2. Gel loading buffer (6×stock solution), (Fermentas, lot No: ooo56239).

The components were dissolved in sterile double distilled water and stored covered with aluminum foil at room temperature.

1.3. DNA ladder (molecular marker): $185 \& 160 \mathrm{bp}$ (Fermentas, lot No: 00052518).

1.4. $5 \mathrm{X}$ Taq master (Fermentas): Containing polymerase enzyme, Magnesium chloride $\left(\mathrm{Mg} \mathrm{Cl}_{2}\right)$, Deoxy nucleotide triphosphate (dNTP) and PCR grade water.

1.5. Primer sequences of Staphylococcus spp. used for PCR identification system:

Application of PCR for identification of mecA, icaA and icaD genes of Staphylococcus spp. was performed essentially by using Primers (Pharmacia Biotech) as shown in the following Table 1.

Table 1: Primers sequences, target genes, amplicon sizes.

\begin{tabular}{|c|c|c|c|}
\hline Target gene & Oligonucleotide sequence $\left(5^{\prime} \rightarrow 3^{\prime}\right)$ & $\begin{array}{l}\text { Amplicon } \\
\text { length (bp) }\end{array}$ & Reference \\
\hline $\operatorname{mec} A(\mathrm{~F})$ & $5^{\prime}$ TAG AAA TGA CTG AAC GTC CG '3 & \multirow{2}{*}{154} & \multirow{2}{*}{ Martín et al. (2004) } \\
\hline$m e c A(\mathrm{R})$ & 5' TTG CGA TCA ATG TTA CCG TAG '3 & & \\
\hline$i c a A(\mathrm{~F})$ & 5' TCT CTT GCA GGA GCA ATC AA'3 & \multirow[b]{2}{*}{188} & \multirow[b]{2}{*}{ Shusheng et al. (2013) } \\
\hline$i c a A(R)$ & 5' TCA GGC ACT AAC ATC CAG CA'3 & & \\
\hline$i c a D(\mathrm{~F})$ & 5' ATG GTC AAG CCC AGA CAG AG '3 & \multirow{2}{*}{346} & \multirow{2}{*}{ Shusheng et al. (2013) } \\
\hline$i c a D(\mathrm{R})$ & 5' CGT GTT TTC AAC ATT TAA TGC AA'3 & & \\
\hline
\end{tabular}

\section{DNA preparation from bacterial culture (Iorio} et al., 2001):

After overnight culture on brain-heart infusion agar plates, one or two colonies were suspended in $20 \mathrm{ml}$ of sterile distilled water, and the suspension was then heated at $100^{\circ} \mathrm{C}$ for 20 minutes. From this suspension, a $5 \mu \mathrm{l}$ aliquot was directly used as a template for PCR amplification.

\section{DNA amplification reaction of Staphylococci} (Jukes et al., 2010):

The amplification was performed on a Thermal Cycler (Master cycler, Eppendorf, Hamburg, Germany) using $25 \mu \mathrm{l}$ of PCR mixture containing $3 \mu \mathrm{l}$ of boiled cell lysate, $250 \mu \mathrm{M}$ of each desoxynucleotide triphosphate, $1.5 \mathrm{U}$ of Taq DNA polymerase (Biotools, Madrid, Spain), buffer (20 mM Tris- $\mathrm{HCl} \mathrm{pH} 8.4,50 \mathrm{mM} \mathrm{KCl}$ and $3 \mathrm{mM} \mathrm{MgCl} 2$, Biotools), $1 \mu \mathrm{M}$ of the primers mecA-R, mecA-F; 0.8 $\mu \mathrm{M}$ of $i c a A-\mathrm{R}$, $i c a A-\mathrm{F}$ and $0.8 \mu \mathrm{M}$ of $i c a D-\mathrm{R}$, icaD-F. Amplification conditions were: denaturation for 3 min at $94^{\circ} \mathrm{C}$, followed by 30 cycles of $94^{\circ} \mathrm{C}$ for $1 \mathrm{~min}$, $58^{\circ} \mathrm{C}$ for $1 \mathrm{~min}$ and $72^{\circ} \mathrm{C}$ for $1 \mathrm{~min}$, with final extension at $72^{\circ} \mathrm{C}$ for $5 \mathrm{~min}$. Amplified products were analyzed by $1.5 \%$ of agarose gel electrophoresis stained with ethidium bromide and visualized and captured on UV transilluminator.

\section{RESULTS}

Detailed obtained results were illustrated in Tables 2 - 4.

In this study, from a total of 105 milk samples collected from clinical mastitis cases, 101 samples $(96.2 \%)$ lead to positive culture. The isolated bacteria from 101 positive specimen culture were as shown in Fig. 1.

Among CoNS $(n=17)$ isolates tested for slime production on CRA plates, 13 isolates $(76.47 \%)$ were found to be slime producers [Five from 6 Staph. epidermidis isolates $(83.3 \%)$ and 8 from 11 Staph. saprophyticus isolates $(72.7 \%)$ were positive for slime production, Fig. 2]. 


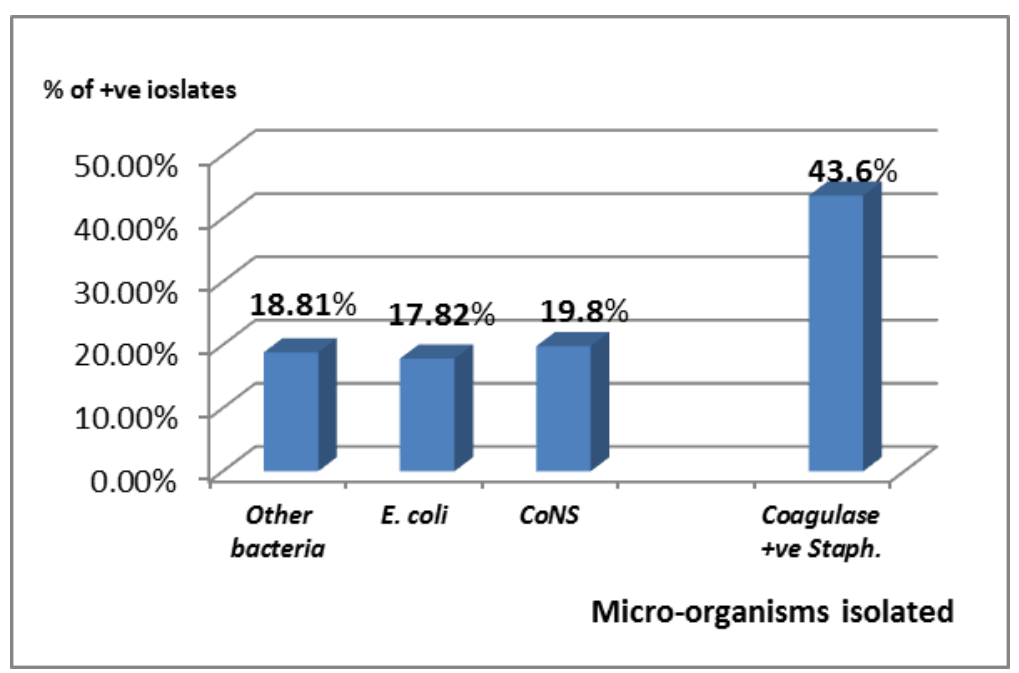

Fig. 1: The percentage of bacterial isolates from bovine clinical mastitis.

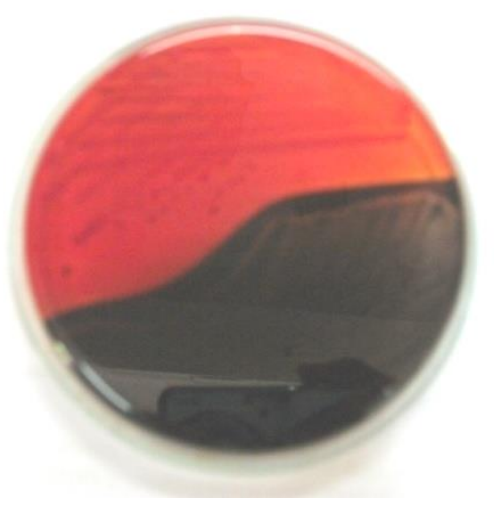

Fig. 2: Congo Red binding test. Above: Non slime producing CoNS isolate (pink colonies). Below: Slime producing CoNS isolate (black colonies).

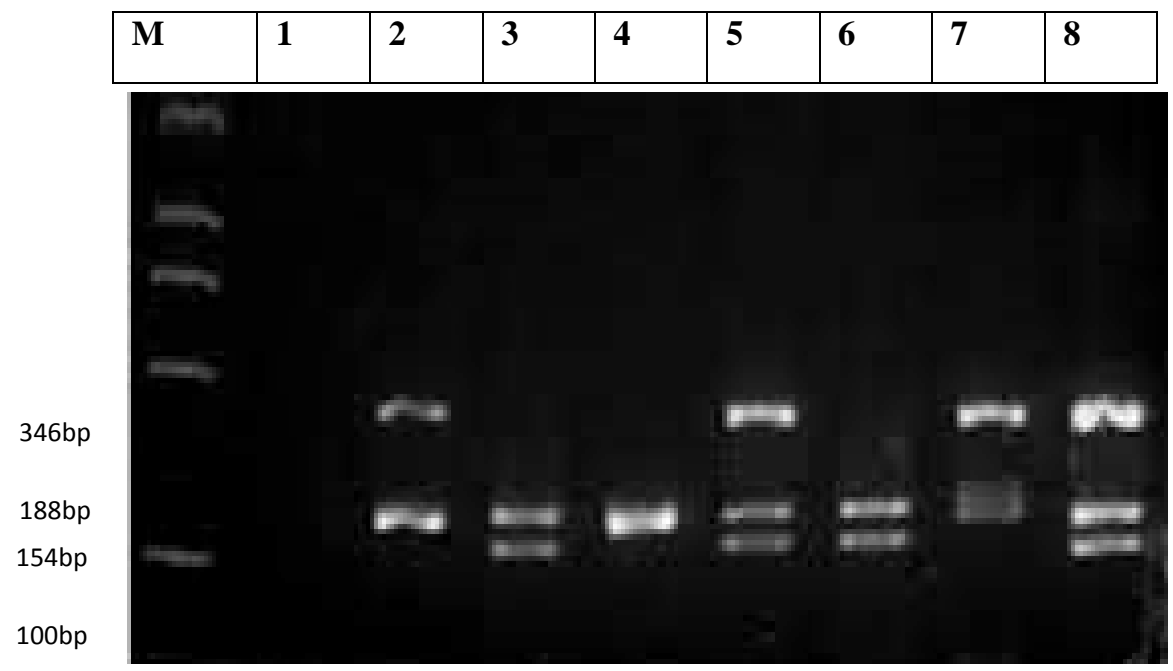

Fig. 3: Agarose gel electrophoresis of PCR of mecA (154 bp), icaA (188 bp) and icaD (346 bp) genes for characterization of S. epidermidis and S. saprophyticus. Lane M: 100 bp ladder as molecular size DNA marker. Lane 1: Control negative for mecA,icaA and icaD genes. Lane 8: Control positive for mecA, icaA and icaD genes. Lane 2: Positive S. saprophyticus for $i c a A$ and icaD genes. Lane 3: Positive S. saprophyticus for mecA and icaA genes. Lane 4: Positive S. saprophyticus for icaA gene. Lane 5: Positive S. epidermidis for mecA, icaA and icaD genes. Lane 6: Positive S. epidermidis for mecA and icaA genes. Lane 7: Positive $S$. epidermidis for icaA and icaD genes. 
$\underline{\text { Assiut Vet. Med. J. Vol. } 61 \text { No. } 144 \text { January } 2015}$

Table 2: Proportions of CoNS in bovine clinical mastitis milk samples $(n=101)$.

\begin{tabular}{cccccc}
\hline $\begin{array}{c}\text { Spices of } \\
\text { CoNS }\end{array}$ & $\begin{array}{c}\text { Staph. } \\
\text { epidermidis }\end{array}$ & $\begin{array}{c}\text { Staph. } \\
\text { saprophyticus }\end{array}$ & $\begin{array}{c}\text { Staph. } \\
\text { chromogenes }\end{array}$ & $\begin{array}{c}\text { Staph. } \\
\text { simulans }\end{array}$ & Total \\
\hline $\begin{array}{c}\text { Number } \\
(\%)\end{array}$ & $\mathbf{6 ( 5 . 9 4 \% )}$ & $\mathbf{1 1 ( 1 0 . 8 9 \% )}$ & $\mathbf{2 ( 1 . 9 8 \% )}$ & $\mathbf{1}(\mathbf{0 . 9 9 \% )}$ & $\mathbf{2 0}(\mathbf{1 9 . 8 \% )})$ \\
\hline
\end{tabular}

Table 3: In vitro antimicrobial susceptibility of CoNS isolated from bovine clinical mastitis $(\mathrm{n}=17)$

\begin{tabular}{|c|c|c|c|c|c|c|}
\hline \multirow{2}{*}{$\begin{array}{c}\text { Antimicrobial } \\
\text { agents }\end{array}$} & \multicolumn{2}{|c|}{$\begin{array}{c}\text { S. saprophyticus } \\
(\mathbf{n} .=11)\end{array}$} & \multicolumn{2}{|c|}{$\begin{array}{l}\text { S. epidermidis } \\
(\mathbf{n} .=6)\end{array}$} & \multicolumn{2}{|c|}{ Total $(\mathbf{n} .=17)$} \\
\hline & Sensitive & Resistant & Sensitive & Resistant & Sensitive & Resistant \\
\hline Oxacillin & $6(54.55 \%)$ & $5(45.45 \%)$ & $1(16.67 \%)$ & $5(83.33 \%)$ & $7(41.18 \%)$ & $10(58.82 \%)$ \\
\hline Enrofloxacin & $11(100 \%)$ & $0(0 \%)$ & $6(100 \%)$ & $0(0 \%)$ & $17(100 \%)$ & $\mathbf{0}(0 \%)$ \\
\hline Gentamicin & $11(100 \%)$ & $0(0 \%)$ & $6(100 \%)$ & $0(0 \%)$ & $17(100 \%)$ & $0(0 \%)$ \\
\hline Doxycycline & $10(90.91 \%)$ & $1(9.09 \%)$ & $6(100 \%)$ & $0(0 \%)$ & $16(94.12 \%)$ & $1(5.88 \%)$ \\
\hline $\begin{array}{l}\text { Trimethoprim - } \\
\text { Sulflamethaxzole }\end{array}$ & $5(45.45 \%)$ & $6(54.55 \%)$ & $5(83.33 \%)$ & $1(16.67 \%)$ & $10(58.82 \%)$ & $7(41.18 \%)$ \\
\hline Oxytetracycline & $7(63.64 \%)$ & $4(36.36 \%)$ & $4(66.67 \%)$ & $2(33.33 \%)$ & $11(64.71 \%)$ & $6(35.29 \%)$ \\
\hline Penicillin & $7(63.64 \%)$ & $4(36.36 \%)$ & $3(50 \%)$ & $3(50 \%)$ & $10(58.82 \%)$ & $7(41.18 \%)$ \\
\hline Ampicillin & $7(63.64 \%)$ & $4(36.36 \%)$ & $2(33.33 \%)$ & $4(66.67 \%)$ & $9(52.94 \%)$ & $8(47.06 \%)$ \\
\hline Cloxacillin & $4(36.36 \%)$ & $7(63.64 \%)$ & $3(50 \%)$ & $3(50 \%)$ & $7(41.18 \%)$ & $10(58.82 \%)$ \\
\hline Cefotaxime & $1(9.09 \%)$ & $10(90.91 \%)$ & $\mathbf{0}(0 \%)$ & $6(100 \%)$ & $1(5.88 \%)$ & $16(94.12 \%)$ \\
\hline Lincomycin & $0(0 \%)$ & $11(100 \%)$ & $\mathbf{0}(0 \%)$ & $6(100 \%)$ & $0(0 \%)$ & $17(100 \%)$ \\
\hline
\end{tabular}

Table 4: Methicillin resistant CoNS strains tested for their phenotypic (slime production) and genotypic characteristics.

\begin{tabular}{|c|c|c|c|c|c|}
\hline \multirow{2}{*}{ No. } & \multirow{2}{*}{$\begin{array}{l}\text { Methicillin resistant coagulase - } \\
\text { negative staph. spp. (MRCoNS) }\end{array}$} & \multirow{2}{*}{$\begin{array}{c}\text { Result on } \\
\text { CRA }\end{array}$} & \multicolumn{3}{|c|}{ PCR results } \\
\hline & & & $\operatorname{mec} A$ & $i c a A$ & icaD \\
\hline 1 & Staphyl. saprophyticus & + ve & -ve & $+\mathrm{ve}$ & $+\mathrm{ve}$ \\
\hline 2 & Staphyl. saprophyticus & $+v e$ & + ve & $+\mathrm{ve}$ & -ve \\
\hline 3 & Staphyl. saprophyticus & -ve & -ve & $+\mathrm{ve}$ & $-v e$ \\
\hline 4 & Staphyl. epidermidis & $+v e$ & +ve & +ve & $+\mathrm{ve}$ \\
\hline 5 & Staphyl. epidermidis & + ve & + ve & $+\mathrm{ve}$ & -ve \\
\hline 6 & Staphyl. epidermidis & + ve & -ve & +ve & $+v e$ \\
\hline
\end{tabular}




\section{DISCUSSION}

For many decades, coagulase-negative staphylococci (CoNS), widely spread in the natural environment and colonizing the skin and mucosa of animals and humans, have been considered non-pathogenic. At present, they are the predominant aetiological factor of bovine mastitis in many countries (Pyörälä and Taponen, 2009 and Bochniarz et al., 2013).Our findings and literature data reveal that the highest incidence of mastitis is caused by bacteria, including coagulase-negative staphylococci prevalent in many countries, according to this study the percentage of CoNS species isolated from milk of cows with clinical mastitis was $19.8 \%$, as shown in Fig. 1 \& Table 2. Similar results of CoNS isolation were obtained byKudinha and Simango (2002); Kurjogi and Kaliwal (2011); Vasil' et al. (2012); Bochniarz et al. (2013); Idriss et al. (2013) and El-Damaty (2013), (22.9; 18.91; 18.8; 23.3; 17.95 and $16.6 \%$, respectively). The high percentage of CoNS $49.6 \%$ and $53.1 \%$ was detected byPitkälä et al. (2004) and Moniri et al. (2007), respectively. While, the low percentage $8.8 \%$ was found by Kalmus et al. (2006).

The CoNS consist of more than 50 species, and are the most frequently isolated pathogens from udder quarters (Larissa et al., 2013). The present work showed that Staph. saprophyticus $(10.89 \%)$ and Staph. epidermidis $(5.94 \%)$ constituted the highest percentage of CoNS species isolated from the milk of cows with clinical mastitis followed by Staph. chromogenes (1.98\%) and Staph. simulans (0.99\%), (Table 2). The results regarding other countries were slightly different. The highest percentage of CoNS species isolated from the milk of cows with mastitis in Japan by Baba et al. (1980) and in Finland by Jarp (1991) was S. epidermidis; in Sweden by Birgersson et al. (1992) was S. simulans; in Poland by Malinowski et al. (2006) and Bochniarz et al. (2013) was S. xylosus. While in Korea, Staph. simulans, Staph. haemolyticus, Staph. sciuri, Staph. xylosus, Staph. epidermidis and Staph. saprophyticus isolates were identified by using biochemical tests from bovine mastitis milk (Moon et al., 2007).

Determination of susceptibility or resistance of strains to antibiotics is very important from a clinical and economic point of view. Moreover, the public health of this issue is of great importance becauseantibiotic therapy of infectious diseases in animals poses the risk of selection of resistant strains and introduction of these strains into the food chain (Lee, 2003). The in vitro activities of CoNS against 11 selected antimicrobial agents are summarized in Table 3 . The highest resistance rate of CoNS observed to Lincomycin (100\%), followed by Cefotaxime (94.12\%), Oxacillin (58.82\%), Ampicillin $(47.06 \%)$ and Penicillin (41.18\%), while the highest rate of sensitivity observed to Enrofloxacin and Gentamicin (100\%, for each), followed by Doxycycline $(94.12 \%)$. Present findings are comparable with the results provided by Moniri et al. (2007) that CoNS species were sensitive to Enrofloxacin (100\%) followed by Kanamycin (92.2\%), and resistance to Penicillin was $56.6 \%$. CoNS bacteria were not Gentamicin-resistant (Gianneechini et al., 2002). Also, Bouman et al. (1999) and Moon et al. (2007) found that 58\% and $60.2 \%$ of CoNS were resistant to Penicillin, respectively. Arslan and Özkardes (2007) recorded that currently, more than $70 \%$ of the CoNS isolates worldwide are resistant to methicillin or oxacillin and in their study found that CoNS clinical isolates were resistant to oxacillin with a percentage $62.1 \%$. Idriss et al. (2014) found that CoNS showed complete sensitivity toTetradelta $(100 \%)$ and higher sensitivity to Enrofloxacin (94.14\%). Tetracycline more effective antibiotics against all bacteria isolated from bovine mastitis (Kurjogi and Kaliwal, 2011). In contrast to our findings, Kaliwal et al. (2011) havebeen reported that 79.41, 76.47, 73.52, 42.94 and $23.23 \%$ of CoNS isolates from bovine mastitis were susceptible toCefotaxime, Methicillin, Ciprofloxacin, Gentamycin and Penicillin, respectively. Idriss $e t a l$. (2014) found that $97.14 \%$ of CoNS isolates were sensitive to Lincomycin. Low resistant of CoNS strains to methicillin (2.4\%) was reported by Moon et al. (2007). Penicillin- resistance found in our study is higher than that previously reported (10 and 5.71\%) for CoNS by Kudinha and Simango (2002) and Kurjogi and Kaliwal (2011), respectively. Coagulase negative staphylococci (CoNS) are capable of causing opportunistic bovine mastitis, many of these strains are resistant to Penicillin or Ampicillin because of the long-term use of $\beta$-lactam antibiotics in agricultural and healthcare settings (Moon et al., 2007). Indiscriminate use of the antibiotics in the farm animal practice coupled with the increasing pathogenicity of the CoNS was suspected to be the issue of major concern (Nagappa and Singh, 2013). The frequency of methicillin-resistant strains in CoNS varies widely among different species, with resistance being predominant in Staph. hominis, Staph. haemolyticus and Staph. epidermidis and infrequent in Staph. capitis and Staph. saprophyticus (Bogado et al., 2001).

$\beta$-Lactam antibiotics are frequently used in intramammary infusion therapy. Bacterial $\beta$-lactam resistance mechanisms include production of $\beta$ lactamases and low-affinity penicillin-binding protein 2a (PBP2a). The latter, designated for methicillin resistance, precludes therapy with any of the currently available $\beta$-lactam antibiotics, and may predict resistance to several classes of antibiotics other than $\beta$-lactams (Odd and Maeland, 1997). 
In the present work the presence of the mecA gene was investigated by PCR, the incidence of methicillin resistance in the tested MRCoNS was $50 \%$ (3/6) by the presence of mecA gene, as shown in Table 4 and Fig 3. The positive detection rates of mecA in MRCoNS were $79 \%$ and $63.2 \%$ by Bogado et al. (2001) and Moon et al. (2007), respectively. In recent years, increased numbers of $\beta$ - lactamase- producing CoNS and mecA- gene positive CoNS (MRCoNS) resistant to all groups of $\beta$-lactam antibiotics have been observed (Moon et al., 2007). In the present study, three $(50 \%)$ CoNS strains were positive phenotypically by disc diffusion method and negative byPCR fordetection of methicillin resistance, (Table 4). The differences between molecular and phenotypic determinations of methicillin resistant was reported by Bogado et al. (2001). The isolates that did not carry mecA were phenotypically resistant to methicillin (Moon et al., 2007). The phenotypic expression of resistance can vary depending on the growth conditions (e.g., the temperature or osmolarity of the medium), making susceptibility testing of MRS by standard microbiological methods potentially difficult (Chambers, 1997). PCR method detecting the mecA gene from staphylococci isolated rapidly and provides a definitive answer for the presence of the mecA gene, whereas the phenotypic tests do not (Moon et al., 2007).

Bacteria in a biofilm are more resistant to antibiotics than in their planktonic form (Melchior et al., 2006).The Congo Red method is rapid, sensitive, practical and reproducible for the detection of slime production in Staphylococcus spp. and has the advantage that colonies remain viable on the medium (Freeman et al., 1989 \& Türkyilmaz and Eskiizmirliler, 2006). In the present study, slime production was examined on Congo Red Agar, 13/17 CoNS isolates $(76.47 \%)$ were found to be slime production positive, result was indicated by black colonies, Fig. 2. These results agreed with that reported $(72.1 \%)$ by Darwish and Asfour (2013). Slime production in CoNS isolates was $47.8 \%$ reported byTürkyilmaz and Eskiizmirliler (2006) and it was $48.7 \%$ in S. epidermidis has found by Mohan et al. (2002). The data reported here indicate an important role of slime production as a virulence marker for $S$. epidermidis, where $83.3 \%$ of the isolated $S$. epidermidis were slime producer. These results similar to those reported by Arslan and Özkardes (2007) who found that clinical CoNS isolates had a high frequency of slime production and drug resistance, particularly S. epidermidis strains.

Combination of phenotypic and genotypic methods recommended for identifying biofilm producing strains. The intercellular adhesion (ica) locus, consisting of the genes icaADBC, has been reported to have a potential role as a virulence factor in the pathogenesis of mastitis in ruminants (Vasudevan et al., 2003). Among the ica genes, icaA and icaD have been reported to play a significant role in biofilm formation in S. aureus and $S$. epidermidis, (Gotz, 2002). In this study, slime factor production of methicillin resistant coagulase - negative Staph. spp. (MRCoNS) isolates were detected by PCR targeting $i c a A$ and $i c a D$ genes and found that $3(50 \%)$ of the tested MRCoNS strains were positive for both icaA and icaD genes. Six (100\%) and three $(50 \%)$ isolates were positive for icaA gene and icaD gene, respectively. In addition one isolates out the six CoNS isolates $(16.67 \%)$ was positive for the presence of icaA, icaD and mecA genes and also has the ability to produce slime as one of the most important virulence factor, as shown in Table 4 and Fig. 3 . The prevalence rates of icaA and icaD genes were $5.9 \%$ and $47.1 \%$ in CoNS isolated from bovine subclinical mastitis, respectively (Darwish and Asfour, 2013). This difference in the prevalence rates can be attributed to variation in DNA sequences which may lead to failed amplification of the gene in some isolates leading to false negative results (Tormo et al., 2005). In the present study, all CoNS isolates which positive for slime production on CRA plates were also positive for detection of icaA gene andsome isolates were positive for presence of icaD gene by PCR (Table 4). Vasudevan et al. (2003) argued that a better methodology for biofilm detection is to screen strains for ica genes in addition to CRA or MTP methods not to miss the genotypically positive phenotypically negative strains.

Conclusion, the findings of the present study demonstrated the ability of CoNS isolated from bovine clinical mastitis to form biofilms. This must be considered as an alarming situation, and so attention must be paid toward implementation of new ways for effective prophylaxis, control, and treatment of such infections in the dairy farms. The prudent use of antibiotics and rapid and continuous screening for resistant microorganisms should be more focused to prevent the emergence and spread methicillin resistant coagulase negative staphylococci, because these strains can cause severe damage to infected sites and may be widespread in the environment.

\section{REFERENCES}

Archer, G.L. and Niemeyer, D.M. (1994): Origin and evolution of DNA associated with resistance to methicillin in staphylococci. Trends Microbiol., 2:325-347.

Arslan, S. and Özkardes, F. (2007): Slime production and antibiotic susceptibility in staphylococci isolated from clinical samples. Mem Inst Oswaldo Cruz, Rio de Janeiro, 102(1): 29-33.

Baba, E.; Fukata, T. and Matsumoto, H. (1980): Ecological studies on coagulase-negative 
staphylococci in and around bovine udder. Bull Univ. Osaka Pref. Ser. B., 32: 69-75.

Birgersson, A.; Jonsson, P. and Holmberg, O. (1992): Species identification and some characteristics of coagulase-negative staphylococci isolated from bovine udders. Vet. Microbiol., 31: 181-189.

Bochniarz, M.; Wawron, W. and Szczubiat, M. (2013): Coagulase-negative staphylococci (CNS) as an aetiological factor of mastitis in cows. Polish Journal of Veterinary Sciences, 16(3): 487-492.

Bochniarz, M. and Wawron, W. (2012): Haemolytic and proteolytic activity of coagulase-negative staphylococci isolated from mastitis cows. Pol. J. Vet. Sci. 15: 61-65.

Bogado, I.; Sutich, E.; Krapp, A.; Marchiaro, P.; Marzi, J.; Putero, M. and Carrillo, N. (2001): Methicillin resistance study in clinical isolates of coagulase-negative staphylococci and determination of their susceptibility to alternative antimicrobial agents. J. of Applied Microbiology, 91: 344-350.

Bouman, M.; Irigoyen, D. and Bertón, A. (1999): Analisis de los resultados de 427 muestras remitidas para aislamiento de bacterias de mastitis y antibiograma. (Study of results from 427 milk samples remitted for bacteriologic cultures and susceptibility testing against antimicrobial agents). Jornadas de Salud de Ubre, Nva. Helvecia, Uruguay. 59-68.

Chambers, H.F. (1997): Methicillin resistance in staphylococci: Molecular and biochemical basis and clinical implications. Clinical Microbiology Reviews, 10: 781-791.

Cucarella, C.; Tormo, M.A.; Ubeda, C.; Trotonda, M.P.; Monzon, M.; Peris, C.; Amorena, B.; Lasa, I. and Penades, J.R. (2004): Role of biofilm-associated protein Bap in the pathogenesis of bovine Staphylococcus aureus. Infection and Immunity, 72: 2177-2185.

Darwish, Samah, F. and Asfour, Hanaa A.E. (2013): Investigation of biofilm forming ability in staphylococci causing bovine mastitis using phenotypic and genotypic assays. Scientific World J., Article ID 378492, 9 P.

De Lencastre, H.; Figueiredo, A.; Urban, C.; Rahal, J. and Tomasz, A. (1991): Multiple mechanisms of methicillin resistance and improved methods for detection in clinical isolates of Staphylococcus aureus. Antimicrobial Agents and Chemotherapy, 35: 632-639.

El-Damaty, Hend, M.S. (2013): Study on the contagious and environmental bovine mastitis with special emphasis to subclinical form. Ph.D. Thesis, Infectious diseases. Fac. of Vet. Med. Zagazig Unvi. Egypt.

Freeman, D.J.; Falkiner, F.R. and Keane, C.T. (1989): New method for detecting slime production by coagulase negative staphylococci. J. Clin. Pathol.; 42: 872-874.

Gianneechini, R.E.; Concha, C. and Franklin, A. (2002): Antimicrobial susceptibility of udder pathogens isolated from dairy herds in the west littoral region of Uruguay. Acta Vet. Scand., 43: 31-41.

Gotz, F. (2002): Microreview on Staphylococcus and biofilms. Molecular Microbiology, 43: 13671378.

Idriss, Sh.E.; Foltys, V.; Tančin, V.; Kirchnerová, K.; Tančinová, D. and Zaujec, K. (2014): Mastitis pathogens and their resistance against antimicrobial agents in dairy cows in Nitra, Slovakia. Slovak J. Anim. Sci., 47(1): 33-38.

Idriss, Sh.E.; Foltys, V.; Tančin,V.; Kirchnerová, K. and Zaujec, K. (2013): Mastitis pathogens in milk of dairy cows in Slovakia. Slovak J. Anim. Sci., 46(3): 115-119.

Iorio, N.; Azevedo, M.; Frazão, V.; Barcellos, A.; Barros, E.; Pereira, E.; Cláudio S.; Kátia R.N. and Dos Santos, K. (2001): Methicillinresistant Staphylococcus epidermidis carrying biofilm formation genes: Detection of clinical isolates by multiplex PCR. Inter. Microbiol., 14: 13-17.

Jarp, J. (1991): Classification of coagulase-negative staphylococci isolated from bovine clinical and subclinical mastitis. Vet. Microbiol., 27: 151-158.

Jukes, L.; Mikhail, J. and Mannathoko, B. (2010): Rapid differentiation of Staphylococcus aureus, Staphylococcus epidermidis and other coagulase-negative staphylococci and methicillin susceptibility testing directly from growth-positive blood cultures by multiplex real-time PCR. J. Med. Microbiol., 59: 1456-1461.

Kaliwal, B.B.; Sadashiv, S.O.; Kurjogi, M.M. and Sanakal, R.D. (2011): Prevalence and antimicrobial susceptibility of coagulasenegative staphylococci isolated from bovine mastitis. Veterinary World, 4(4):158-161.

Kalmus, P.; Viltrop, A.; Aasmae, B. and Kask, K. (2006): Occurrence of clinical mastitis in primiparous Estonian dairy cows in different housing conditions. Acta Vet. Scand. 48(1): 21-26.

Kudinha, T. and Simango, C. (2002): Prevalence of coagulase-negative staphylococci in bovine mastitis in Zimbabwe. J.S. Afr. Vet. Ass., 73(2): 62-65.

Kurjogi, M.M. and Kaliwal, B.B. (2011): Prevalence and antimicrobial susceptibility of bacteria isolated from bovine mastitis. Advances in Applied Sci. Research, 2 (6): 229-235.

Larissa, A.; Zeni, C.; Jeroen, D.B. and Herman, W.B. (2013): Clinical mastitis caused by coagulasenegative Staphylococci in Canadian dairy 
herds. WCDS Advances in Dairy Technology, Vol. 25, Abstract, p. 373.

Lee, J.H. (2003): Methicillin (oxacillin)-resistant Staphylococcus aureus strains isolated from major food animals and their potential transmission to humans. Appl. Environ. Microbiol., 69: 6489-6494.

Malinowski, E.; Lassa, H.; Kłossowska, A.; Smulski, S.; Markiewicz, H. and Kaczmarowski, M. (2006): Etiological agents of dairy cows' mastitis in western part of Poland. Pol. J. Vet. Sci., 9: 191-194.

Martín, L.; Díez, G.; Morales, M.; Batista, N.; Villar, J.; Claverie, F. and Méndez, A. (2004): Simultaneous PCR detection of ica cluster and methicillin and mupirocin resistance genes in catheter-isolated Staphylococcus. Inter. Microbiol., 7: 63-66.

Melchior, M.B.; Vaarkamp, H. and Fink-Gremmels, $J$. (2006): Biofilms: A role in recurrent mastitis infections? Vet. J. 171: 398-407.

Mohan, U.; Jindal, L. and Aggarwal, P. (2002): Species distribution and antibiotic sensitivity pattern of coagulase negative staphylococci isolated from various clinical specimens. Indian J. Med. Microbiol., 20: 45-46.

Moniri, R.; Dastehgoli, K. and Akramian, A. (2007): Increasing resistant coagulase negative staphylococci in bovine clinical mastitis. Pakistan J. of Biological Sci.,10 (15): 2465-2469.

Moon, J.S.; Lee, A.R.; Kang, H.M.; Lee, E.S.; Kim, M.N.; Paik, Y.H.; Park, Y.H.; Joo, Y.S. and Koo, H.C. (2007): Phenotypic and genetic antibiogram of methicillin-resistant staphylococci isolated from bovine mastitis in Korea. J. Dairy Sci.; 90: 1176-1185.

Nagappa, S.K. and Singh, S.P. (2013): Isolation and antibiogram of coagulase negative Staphylococci from bovine mastitic milk. Journal of Food borne and Zoonotic Diseases, 1(1): 21-23.

NCCLS (National Committee For Clinical Laboratory Standards), (2002): Performance Standards for Antimicrobial Disk and Dilution Susceptibility Tests for Bacteria Isolated from Animals. Approved Standard. NCCLS Document M31-A2, Wayne, PA.

Odd, G.B. and Maeland, J.A. (1997): Mechanism of methicillin resistance in staphylococci. APMIS 105: 264-276.

Oliveira, M.; Bexiga, R.; Nunes, S.F.; Carneiro, C.; Cavaco, L.M.; Bernardo, F. and Vilela, C.L. (2006): Biofilm-forming ability profiling of
Staphylococcus aureus and Staphylococcus epidermidis mastitis isolates. Vet. Microbiol. 118: 133-140.

Pitkälä, A.; Haveri, M.; Pyörälä, S.; Myllys, V. and Honkanen-Buzalski, T. (2004): Bovine mastitis in Finland 2001-prevalence, distribution of bacteria, and antimicrobial resistance. J. Dairy Sci., 87: 2433-2441.

Pyörälä, S. and Taponen S. (2009): Coagulasenegative staphylococci emerging mastitis pathogens. Vet. Microbiol., 134:3-8.

Quinn, P.J.; Carter, M.E.; Markey, B. and Carter, G.R. (2004): Clinical veterinary microbiology. $6^{\text {th }}$ ed., Mosby, Edinburgh, London, New York, Philadelphia, St. Louis, Sydney, Toronto.

Shusheng, Z.; Xiaoguang, C.; Mingming, F.; Yuanyuan, D. and Bao, L. (2013): Analysis of $S$. epidermidisicaA and $i c a D$ by polymerase chain reaction and slime production: A case control study. Infect. Dis., 13: 242-248.

Stevens, N.T.; Tharmabala, M.; Dillane, T.; Greene, C.M.; O'Gara, J.P. and Humphreys, $H$. (2008): Biofilm and the role of the ica operon and aap in Staphylococcus epidermidis isolates causing neurosurgical meningitis. Clin. Microbiol. Infect. 14:719-722.

Tormo, M.Á.; Knecht, E.; Götz, F.; Lasa, I. and Penadés, J.R. (2005):Bap-dependent biofilm formation by pathogenic species of Staphylococcus: Evidence of horizontal gene transfer?. Microbiology, 151(7): 2465-2475.

Türkyilmaz, S. and Eskiizmirliler, S. (2006): Detection of slime factor production and antibiotic resistance in staphylococcus strains isolated from various animal clinical samples. Turk. J. Vet. Anim. Sci., 30: 201-206.

Unal, S.; Hoskins, J.; Flokowitsh, J.E.; Wu, C.Y.; Preston, D.A. and Scatrud, P.L. (1992): Detection of methicillin-resistant staphylococci by using the polymerase chain reaction. Journal of Clinical Microbiology, 30: 1685-1691.

Vasil, M.; Elečko, J.; Zigo, F. and Farkašová, Z. (2012) :Occurrence of some pathogenity factors in coagulase negative staphylococci isolated from mastitis milk in dairy cows. Potravinárstvo, 6(2):60-63.

Vasudevan, P.; Nair, M.K.; Annamalai, T. and Venkitanarayanan, K.S. (2003): Phenotypic and genotypic characterization of bovine mastitis isolates of Staphylococcus aureus for biofilm formation. Veterinary Microbiology, 92 (1-2): 179-185. 
الكثف عن المكور العنقودي السالب لإنزيم التجلط والمقاوم للميثاسلين والمفرز لعوامل الالتصاق المسبب لالتهاب الضرع الإكلينيكي في الأبقار باستخلمام تفاعل البلمرة المتنسلسل

سعد محروس البرباوي ، سيل محمد سبي ، عصام إسعاعيل الطوخي ، أمل أحمد مجاهد

Email: saadelberbawy@yahoo.com

هدفت هذه الدر اسة إلي التحقق من أنتاج البيوفيلم في المكورات العنقودية السالبة لإنزيم التجلط و المقاو مة للميثاسلين باعتباره و احدا من

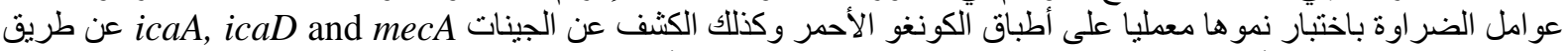

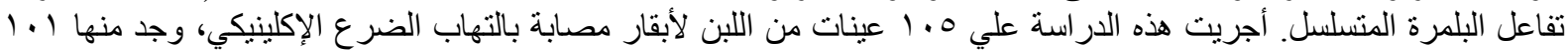

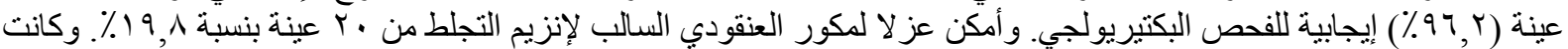

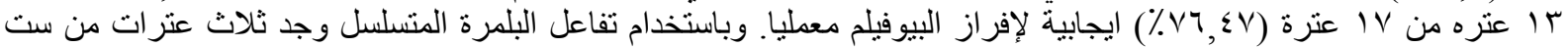

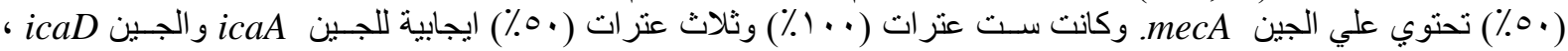

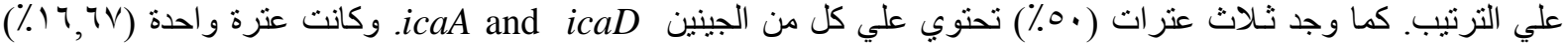

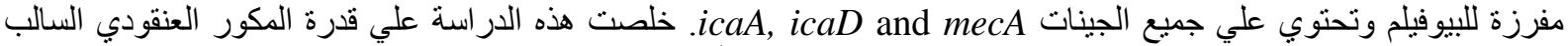

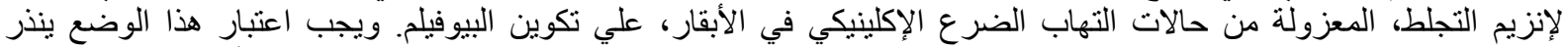

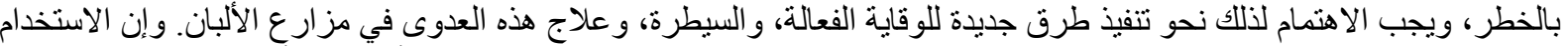

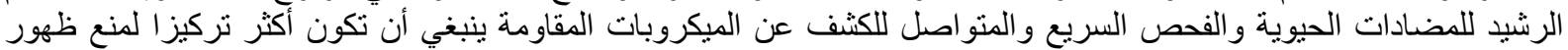

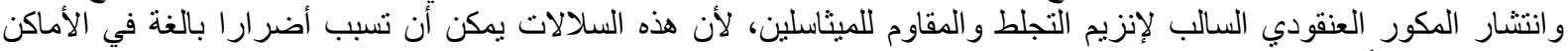
المصابة ويمكن أن تكون واسعة الانتشار في البيئة. 